\title{
The challenge of neoliberalism and precarity for gender sensitivity in academia
}

\author{
Rodrigo Rosa and Sara Clavero
}

\section{Introduction}

In recent decades, academic institutions have been expected to become more gender-sensitive organisations (see Chapter 1). In a number of countries, this has already become an imperative to attract high-quality students, world-class academic staff and prestigious research funding which explicitly requires a commitment to gender equality policy implementation. However, the complex interweaving of the gendered distribution of power and division of labour, underlined by a continuing masculinist organisational culture, has been reinforced through a growing neoliberal ethos. This chapter addresses some current challenges that academic organisations face in the pursuit of gender equality in this context. It examines the gender impact of new managerialism; the emergence of a new precarious, predominantly female, academic 'underclass' of teachers and researchers; approaches to identities as diverse, fluid and interconnected, rather than fixed; and how these identities intersect with power relations in academic institutions and in feminist scholarship.

\section{The neoliberal university}

There is a growing literature investigating the impact of neoliberalism on the nature, organisation and purpose of academia and the challenges for academics working within institutions of higher education. Neoliberal policies in the public sector draw upon New Public Management (NPM), an approach developed in the United Kingdom and Australia during the 1980s as part of an effort to make the public sector more businesslike and to improve efficiency by using private sector management models (see Chapter 11). These policies, combining free market rhetoric and intensive managerial control practices, have been extensively applied in higher education organisations in a market-driven demand for growth and efficiency (Lorenz 2012). As a result, academic work has become increasingly stressful at the same time as gender inequalities have been perpetuated (Acker and Armenti 2004). The pathways towards gender equality in higher education today are at a crossroads: how to strive for a gender-sensitive university while 
the institutions themselves experience government funding cuts, restructuring and downsizing as a consequence of neoliberal economic trends. This dilemma underlies the literature on the gendered effects and challenges of neoliberalism in academia.

Research shows that the demands that have emerged in neoliberalised academic institutions have resulted in highly gendered outcomes, since it is female academics who experience work-life conflict more often than their male colleagues. Hence they are more likely to consider leaving academia early (see Chapter 5). Bomert and Leinfellner observed pessimistically that 'family-centred and heteronormative values are represented within an understanding of childlessness as one of the best prerequisites for an academic career' $(2017,119)$. Other writers have highlighted the importance of institutional support and collective engagement, particularly for early career academics struggling to combine work and family obligations, in increasingly precarious work environments. For example, Hawkins et al (2014) examined how $\mathrm{PhD}$ students combined work and family life within complex power relations at work. The authors concluded that the task of academics 'against neoliberal academia is not merely to seek work-life balance so that the work part of the equation can continue its oppressive and exploitative function' (Hawkins et al 2014, 347). Lipton (2017) observed the complex and conflicting entanglements of neoliberal and gender equity discourses by focusing on women's career decisions. The study showed that while being used as statistical tools to track and quantify gender equality, policies are also "operational tools for neoliberalising higher education, in that they "assure" quality and accountability, increasing competition and production', making women 'hyper visible and thus responsible for their own success or failure' (Lipton 2017, 487-489).

In recent years, the focus has shifted to a younger generation of academics and their responses to performativity expectations, based on the new academic ideal worker. Is it possible to work in academia without becoming a neoliberal subject? This question was explored in a study conducted by Archer which showed that, even considering that 'subjects cannot exist outside of the conditions and locations within which they are located and by which they are constituted', there are 'important moments and spaces of resistance' allowing for critique and resilience (Archer 2008, 282). Other researchers have studied gendered subjects, under prevailing male work norms, in the neoliberal university. Vayreda et al (2019) observed the gendered nature of the neoliberal rationale overrunning the new university; how its spaces 'provide the conditions of possibility to develop a scientific entrepreneurial self, excluding "other" scientific subjectivities and preventing possible resistances that could emerge from them' $(2019,432)$. The study by De Coster and Zanoni (2019) explored women's struggle to (dis)identify with the male work norm under neoliberal governance:

Neoliberal governance functions as a double-edged sword that on the one hand constitutes an increasingly accountable academic subjectivity while on the other constrains the possibility to constitute a female subjectivity that 
is open and responsive through the relations of accountability, fulfilling the gendered norms.

(De Coster and Zanoni 2019, 413)

There is an increasing scholarly interest in the conditions and barriers for combining research with a feminist approach in the neoliberal university. Some authors have reflected upon the striking resonance between neoliberalism and postfeminist sensibility, which particularly emphasises the constant surveillance, monitoring and disciplining of the self. For example, Gill contends that postfeminism urges "the "right" kinds of dispositions for surviving in neoliberal society: aspiration, confidence, resilience and so on' $(2017,610)$. Meyers points out how postfeminist and neoliberal discourses 'intersect within the lives of academic women [and are] neglected as an area of study' (2013, 276). More recently, Rumens (2018) explored this connection between postfeminist and neoliberal discourses by focusing on the challenges he encountered in teaching gender equality to students in a business school. He found that 'postfeminist discourses can stifle discussion on gender equality ... female students can vocalise a postfeminist sensibility that drains gender and feminism of its political valence' as well as inferring that it is for students themselves to overcome gender discrimination (Rumens 2018, 339). Some authors have even questioned the possibility of being an academic with feminist commitments, in the current postfeminist and neoliberal climate (Acker and Wagner 2019; Pereira 2016).

\section{Gender equality and intersectionality}

Tackling gender inequalities in academia requires dealing with the wide range of thematic areas covered in the chapters of this book and by researchers across Europe (Husu 2019; Winchester and Browning 2015; Sagaria 2007; Mason and Goulden 2004; Baylin 2003). While strategies for achieving equality in gendered institutions have become increasingly professionalised (Ikävalko and Kantola 2017), a further debate on gender equality and equity has taken place. Here, writers have criticised equality-led initiatives for lacking efficiency or failing to acknowledge the complexity of different structural, cultural and institutional factors affecting female academics (Schmidt and Cacace 2018). Until recently, institutional thinking on areas of disadvantage focused on narrow social categories such as gender binaries, LGBTQI+, race and ethnicity. The growing literature devoted to the importance of an intersectional approach seeks to widen the general discourse around equality, diversity and inclusion.

In order to explore the gendered processes of exclusion inherent in academia, a growing number of researchers favour a critical approach to gender which is not restricted to fixed dichotomies, in favour of within-gender differences, as well as incorporating an intersectional approach. This reflects the realisation that knowledge production is not only a male enterprise but also a predominantly white and economically privileged undertaking. Intersectional approaches have the potential 
to disrupt a number of problematic trends in sex/gender research, including binary constructions of sex (male versus female) and gender (masculine versus feminine), the treatment of sex and gender as easily separable and the disconnection of sex/gender from other significant identities. The increasing complexity of advancing gender equality in academia requires going beyond gender to interventions that develop intersectionality and critical approaches to equality (LERU 2019).

The idea that people are often disadvantaged by multiple and overlapping sources of oppression - their gender, ethnicity, class, gender identity, sexual orientation, religion, body ability and other identities - is now an accepted way of thinking about disadvantage and difference. Some women may choose to privilege gender as their identity marker; that is their choice. For most women and men, however, it is the way in which many other parts of their identity come into play alongside gender in their professional lives in academia, and their private lives away from it, that determine their intellectual ambition and agency. Intersectionality has a place in recognising and celebrating differing interwoven identities in teaching and research, in how academic institutions are designed and managed, how safe they are for those who inhabit them, how they are funded, who gets admitted to them, who the teachers and researchers are, what is taught and how, the ways in which research is framed and conducted, how and what language is used, who is in charge and how they got there.

Adopting an intersectional approach replaces assumptions about policies that will be unilaterally advantageous for all women irrespective of their other identities. Instead, the intersection of gender with these other identities is foregrounded. Intersectionality allows an examination of how, for example, women experience different obstacles to career advancement according to their race and ethnicity, body ability or age entering academia, their role as parents or as carers. For example, whilst one professorial position in four $(25 \%)$ is held by a woman in the UK (European Commission 2017) the equivalent proportion for black and minority ethnic (BME) women is less than 2 per cent (Solanke 2017). An intersectional framework is able to unveil the inbuilt, interwoven inequalities and injustices in this situation as a prerequisite to finding the optimal policies for countering multiple disadvantage, rather than providing add-on policy measures that are typical of many diversity perspectives. Some recent literature has shown that standing at the intersection of different identity groups does not necessarily result in the accumulation of disadvantage. Research taking an intersectional perspective addresses the complex interconnectedness and consequences of different forms of inequality and otherness. Two studies, outlined here, show this by investigating the relationship between gender and foreignness, and gender and political identity.

Strau $\beta$ and Boncori (2020) explore how gender intersects with foreignness by using the concept of the 'double-stranger' in examining the experiences of foreign female scholars working across geographic boundaries. The study demonstrates the different dynamics and temporary hierarchies between different forms of strangeness (being foreign and being a woman). Their work shows that these 
forms can function as categories of disadvantage or resources for resistance; they are not simply additive; and they may develop over time:

While being woman appears to be a rather constant form of estrangement in othering academics within their professional environment, the category of foreignness is more subject to change over time, as it can improve after an initial period of adjustment to then become dormant, with the occasional threat turning into a destabilising factor for the participants' sense of belonging.

(emphasis added; Strau $\beta$ and Boncori 2020, 26-27)

Drawing upon focus groups with self-identified feminist academics, Sang's recent study (2018) explores the heterogeneity of women's experiences in academia, where gender intersects with political identity and ethnic background. Findings from this study suggest a mixed pattern of experiences. Not only can intersectionality lead to an understanding of disadvantage in relation to social identities, such as gender and ethnicity, but how a political identity, such as being a feminist, can lead to the accumulation of advantage, since women may use their 'otherness' to strategically challenge and work around existing power relations. Some feminist academics argue that the intersection of gender and race restricts their ability to identify with a particular ethnic group and may result in marginalisation. For other women, being a feminist intersects with these identities, thereby creating a space for critiquing the status quo within their institutions (Sang 2018).

As early as 1978 the poet, academic and activist Lorde chose to define herself as black, lesbian, feminist, mother, poet and warrior, and also as a survivor of cancer. She refused to define herself, even temporarily, by any one aspect of her heterogeneous identity, whether to support a political programme or to make others feel comfortable:

There's always someone asking you to underline one piece of yourself whether it's Black, woman, mother, dyke, teacher etc - because that's the piece that they need to key in to. They want you to dismiss everything else. But once you do that, then you've lost because then you become acquired or bought by that particular essence of yourself and you've denied yourself all of the energy it takes to keep all those others in jail. Only by learning to live in harmony with all your contradictions can you keep it all afloat.

(emphasis in original; Hall 2004, 31)

At its core, intersectionality creates nuanced possibilities of commonality and difference for and within all genders and it offers the opportunity to forge alliances for the work of making academic institutions more gender-sensitive. 


\section{Feminisms and women's/gender studies in the neoliberal university}

There is a burgeoning literature on the impact of neoliberalism on feminisms and women's/gender studies within academia (Morley 2016; Cannella and Salazar-Perez 2012; Gill 2009). Despite a consensus among feminist scholars that the neoliberal university poses significant constraints on feminist action in academic settings, there are also studies that point to the opening up of possibilities to advance gender justice and equality, particularly through new forms of collective organising. Such opportunities and constraints are marred by tensions and contradictions that originate from the strong masculinist nature of the new neoliberal ethos permeating academic structures, procedures and work practices. In this context, the question is whether, how and to what extent can feminism succeed in challenging the neoliberal university?

The neoliberal university is characterised by the requirement of production and accessibility at all times and the use of performance indicators as measures of success, such as continuous research assessments and teaching evaluations. In this environment of neoliberal management, masculine ideologies are perpetuated and reproduced through the celebration of fierce competition, an increased (and stressful) pressure to succeed, making pastoral work invisible, devalued or displaced. There is also pre-eminence of individualist values over traditional values of academic collegiality (Acker and Wagner 2019; Ivancheva et al 2019; Lipton 2019). In addition, the neoliberal university has established new forms of precarious employment, particularly since austerity measures were introduced at the end of the 2000s. In this academic reality, feminist researchers, academics and postgraduate students constitute a new form of 'proletariat' who struggle to survive in a highly competitive and individualistic arena (Gill and Scharff 2013; Davies and O'Callaghan 2014; Nash 2013). Can this new academic environment leave any 'open space' for feminist academics to act freely and develop alternative feminist academic cultures? In addressing this question, the literature highlights two particular challenges. First, for feminist research and teaching, it is marked by the under-resourcing and/or closure of women's and gender studies degrees in many institutions. The second challenge is the possibility of feminist organising for collective action aimed at subverting the current status quo.

In relation to the first challenge, the emergence of gender and women's studies programmes, centres and departments, in the late 1960s and 1970s, were not adopted in all institutions and were not without criticism (Pereira 2012). The avowed commitment by feminist scholars to articulate academic inquiry and political action was invoked by critics as evidence that this work could not be taken seriously as 'proper' scholarship. The institutionalisation of gender and women's studies as a distinct research and teaching category increased its stability and professional credibility. It also gained recognition in national and international contexts, where it had already achieved some institutional autonomy and was increasingly integrated into existing disciplines (Alvanoudi 2009). However, these programmes now run the risk of disappearing from academia, since their 
ability to foster an environment of feminist teaching and research is hampered by the overarching neoliberal impositions of the institution and precarity in relation to staff working conditions (Bendl and Schmidt 2013).

The second challenge posits the view that the feminist struggle for gender equality in academic institutions has moved from feminist bottom-up activism to become part of the official top-down strategy for which university managers are held accountable and may be rewarded if they reach gender equality goals (see Chapter 12). In the view of Sauer and Wöhl (2008) the gender policies that were once empowering strategies of the women's movement now risk losing their critical potential to achieve social change and are becoming instruments that both steer and produce inequality. Other writers point out, however, that some of the current transformations in academia have created new possibilities for the development of forms of publicly and politically engaged academic practice (Pereira 2016). The findings of EU-Horizon 2020 supported interventions in Ireland, Austria, Italy and Turkey further demonstrate the alignment of Gender Equality Plan (GEP) actions to promote gender equality with positive outcomes:

Top down AND bottom up support for GEPs was stressed, as was arriving at a consensus as to what could/should be done. Flowing from this was the perceived need to institutionalise gains and the development of a communications strategy (using gender sensitive language) to convey the message of gender equality needs/successes to all stakeholders.

(Drew and Bencivenga 2017, 351)

Against the backdrop of broader discourses of austerity, there is now an increased emphasis on the idea that investment in academia must provide the best value for tax-payers' money by engaging with, and having effects on, communities and sectors outside the academy (Collini 2012). There are concerns that the measurement of 'impact' is primarily focused on income-generation for business and industry and direct influence on public policy (Holmwood 2001; Atwood 2010). This is confirmed by a desire to reconceptualise and reposition universities as institutions subordinated to, and shaped by, the needs of the economy and the demands of the market. This reflects an understanding of education and research that clearly clashes with key principles of feminist theory and politics (Evans 2004). Pereira's study (2016) shows, how institutional views on feminist activism have begun to shift. If feminists' political intervention is understood as something that can enhance the social, political and media visibility of their institution, it becomes reframed as valuable work that can lead to better research ratings and increased recruitment. Chapter 6 provides a detailed case study of the way in which feminist activism, in response to sexual violence on one large university campus, had this effect.

\section{Precarity}

The transformation of academic work into an individual and competitive endeavour is a consequence of pervasive neoliberal practices in higher education institutions. 
These are increasingly dependent on unstable employment contracts (part time, fixed term, zero hours). Three areas of study address the intersection of precarious work and gender in this context.

One area focuses on the intersection of unpaid care work outside academia and precarious paid work within it. Drawing on 102 semi-structured in-depth interviews with female and male academics, Ivancheva et al showed that, even if male academics face precarity challenge due to labour segmentation, the relational aspect of precarity is not a major male preoccupation for them in their work narratives. For while 'both contractual and affective precarity operate coterminously for women, each poses significant limitations to a sense of security' $(2019,457)$. Women researchers' autobiographical experiences, aimed at rendering precarity and its ramifications more visible by exploring their lived experience, are contributing to this growing body of literature (Caretta et al 2018). This work shows how, for example, precarious working conditions and maternity combine to intensify precarity itself (Téllez 2018). Hofmann (2018) testifies to the toll of precarity contributing to the distress, financial insecurity and impossibility of planning a future, in terms of careers or personal relationships, alongside difficulties in finding secure housing. These consequences result in dependency on the goodwill of more senior academics and the accompanying sense of subservience that it can produce.

A second area is focused on studies that expose the differing status of men and women in academia who have no permanent contracts. One qualitative study explored the 'non-citizen' status of female academics who identified as precarious workers (O'Keefe and Courtois 2019). The majority were women working in social sciences and humanities (SSH), traditionally perceived as more hospitable for women, compared with science, technology, engineering and mathematics (STEM) disciplines. Among academics working in less desirable forms of precarious work 'women were especially concentrated in forms of temporary work that is hourly paid or based on pro-rata and zero hours contracts while men were more likely to be on yearly or multi-year contracts' (O'Keefe and Courtois 2019, 469). In addition, the findings suggest that 'the length of time spent performing precarious academic labour is also gendered, as women are more likely to have worked in the sector longer than their male counterparts' (O'Keefe and Courtois $2019,469)$. The authors stress that often the institutional proposals to tackle gender inequality do not extend to academics in precarious employment, tending instead to focus on access to the senior ranks and leadership. Conversely, as their findings suggest, "the "leaky pipeline" trend visible in the tenured ranks may continue' unless the ranks below are examined and anomalies addressed (O'Keefe and Courtois 2019, 469).

There is a third strand of literature that examines action research undertaken under equality initiatives. One example is a set of studies carried out as part of the European Union funded project GARCIA (Gendering the Academy and Research: Combating Career Instability and Asymmetries), a project which focused on both the top positions and early stages of academic and research careers. The study by Dubois-Shaik et al (2019) identified three types of gendered careers and experiences: first, the persistence of precarious career paths, which produces a high 
cumulative cost for the individuals concerned; second, continuing in ambivalent career paths, producing moderate cost; and third, striving to win in competitive career paths, which comes at specific high cost to individuals. A study by Steinpórsdóttir et al (2019) examined how neoliberal managerialism fosters the process of precarity in academic employment by promoting organisational practices and funding which tends to favour male-dominated STEM departments. Finally, the comparative study by Herschberg et al (2019) analysed how gender interferes with the construction of excellence in recruitment and selection practices for early career researchers in the STEM and SSH institutes, as well as the consequences of the gendered construction of the 'ideal candidate' for those academics with precarious work contracts (see Chapter 3).

\section{Conclusion}

This chapter highlights relevant recent studies on the neoliberalisation of academia, focusing on key issues not specifically addressed in other chapters of this book, namely, gender equality and intersectionality, feminisms, gender studies and precarity. It shows that gender equality is a particularly challenging goal in a context where the changes introduced by neoliberal management practices and the resulting demands imposed on academic staff are themselves gendered. Against this backdrop, the literature shows that postfeminist and neoliberal discourses intersect in female academic lives and women struggle to (dis)identify with the male work norm under neoliberal governance. Discourses question the attainability of a healthy work-life balance in a climate where scholarly work continues to be oppressive and exploitative; where many feminist scholars experience exhaustion and self-doubt, exacerbated by an unwillingness to collude with unchanging gendered work practices.

An understanding of the subtleties of intersectionality offers the possibility of critical approaches to traditional understandings. Examining the intersections between gender and other forms of inequality, identity and otherness is one approach. It remains a major challenge to define best practice to assess and address how all inequalities intersect in academia. Not only does the intersectionality framework show how social identities such as gender, ethnicity and family status, for example, combine to produce disadvantage, it also shows that women can use their otherness to strategically challenge and work around existing power relations.

The impact of current transformations in academic governance on possibilities for feminist mobilisation is complex. New management models impose strict requirements for enhanced productivity, which in turn significantly limit the time and energy that feminist scholars have available for social and political intervention and for community-based or advocacy research. However, those same transformations are opening up new possibilities for activism. They offer increasing institutional recognition of, and support for, feminist scholars' work with political allies and civil society organisations outside the academy. Recent studies addressing the intersection of precarious work and gender in academia show that women 
are especially concentrated in the most undervalued forms of precarious work in academia and that an interrogation of intersectionality throughout academia is required for a more nuanced analysis and the formulation of policies for change.

\section{References}

Acker, S. and Armenti, C. (2004) Sleepless in academia, Gender and Education, 16 (1), 3-24, doi:10.1080/0954025032000170309

Acker, S. and Wagner, A. (2019) Feminist scholars working around the neoliberal university, Gender and Education, 31 (1), 62-81, doi:10.1080/09540253.2017.1296117

Alvanoudi, A. (2009) Teaching gender in the neoliberal university, in D. Gronold, B. Hipfl and L. Pedersen (eds), Teaching with the third wave: New feminists' explorations of teaching and institutional contexts, ATHENA, Utrecht, 37-54. Available at: https://atgen der.eu/wp-content/uploads/sites/207/2017/08/Teaching_With_The_Third_Wave.pdf

Archer, L. (2008) The new neoliberal subjects? Young/er academics' constructions of professional identity, Journal of Education Policy, 23 (3), 265-285, doi:10.1080/02680 930701754047

Atwood, R. (2010) Impact's impact could be the stifling of new ideas, Times Higher Education. Available at: www.timeshighereducation.co.uk/story.asp? storycode $=411487$

Baylin, L. (2003) Academic careers and gender equity: Lessons learned from MIT1, Gender, Work \& Organization, 10 (2), 137-153, doi:10.1111/1468-0432.00008

Bendl, R. and Schmidt, A. (2013) Gender mainstreaming: An assessment of its conceptual value for gender equality, Gender, Work \& Organization, 20 (4), 364-381, doi:10.1111/ j.1468-0432.2011.00584.x

Bomert, C. and Leinfellner, S. (2017) Images, ideals and constraints in times of neoliberal transformations: Reproduction and profession as conflicting or complementary spheres in academia? European Educational Research Journal, 16 (2-3), 106-122, doi. org/10.1177/1474904116682972

Cannella, G. and Salazar-Perez, M. (2012) Emboldened patriarchy in higher education: Feminist readings of capitalism, violence, and power, Cultural Studies Critical Methodologies, 12 (4), 279-286, doi.org/10.1177/1532708612446421

Caretta, M., Drozdzewski, D., Jokinen, J. and Falconer, E. (2018) 'Who can play this game?' The lived experiences of doctoral candidates and early career women in the neoliberal university, Journal of Geography in Higher Education, 42 (2), 261-275, doi: 10.1080/ 03098265.2018 .1434762

Collini, S. (2012) What are universities for? Penguin, London.

Davies, H. and O'Callaghan, C. (2014) All in this together? Feminisms, academia, austerity, Journal of Gender Studies, 23 (3), 227-232, doi.org/10.1080/09589236.2014.913824

De Coster, M. and Zanoni, P. (2019) Governing through accountability: Gendered moral selves and the (im)possibilities of resistance in the neoliberal university, Gender, Work \& Organization, 26 (4), 411-429, doi.org/10.1111/gwao.12304

Drew, E. and Bencivenga, R. (eds) (2017) Gender in Horizon 2020: The case of gender equality plans, AG AboutGender, 6 (12), 326-355, doi.org/10.15167/2279-5057/ AG2017.6.12.488

Dubois-Shaik, F., Fusulier, B. and Vincke, C. (2019) A gendered pipeline typology in academia, in A. Murgia and B. Poggio (eds), Gender and precarious research careers: A comparative analysis, Routledge, London, 178-205, doi.org/10.4324/9781315201245 
European Commission (2017) Modernisation of higher education in Europe: Academic staff2017. Eurydice report. Education Audiovisual and Culture Executive Agency, Brussels.

Evans, M. (2004) Killing thinking: The death of the universities, Continuum, London.

Gill, R. (2009) Breaking the silence: The hidden injuries of neo-liberal academia, in R. Flood and R. Gill (eds), Secrecy and silence in the research process: Feminist reflections, Routledge, London, 228-244. Available at: http://platform-hnu.n 1/wp-content/ uploads/2015/05/gill-breaking-the-silence-2.pdf

Gill, R. (2017) The affective, cultural and psychic life of postfeminism: A postfeminist sensibility 10 years on, European Journal of Cultural Studies, 20 (6), 606-626, doi.org/10. 1177/1367549417733003

Gill, R. and Scharff, C. (eds) (2013) New femininities: Postfeminism, neoliberalism and subjectivity, Palgrave Macmillan, Basingstoke, Hampshire, doi.org/10.1177/095935351 1427291

Hall, J. (ed) (2004) Conversations with Audre Lorde, University Press of Mississippi, Jackson.

Hawkins, R., Manzi, M. and Ojeda, D. (2014) Lives in the making: Power, academia and the everyday, ACME: An International Journal for Critical Geographies, 13 (2), 328351. Available at: www.acme-journal.org/index.php/acme/article/view/1010

Herschberg, C., Benschop, Y. and Van den Brink, M. (2019) The peril of potential: Gender practices in the recruitment and selection of early career researchers, in A. Murgia and B. Poggio (eds), Gender and precarious research careers: A comparative analysis, Routledge, Abingdon, Oxon, 111-142, doi.org/10.4324/9781315201245

Hofmann, S. (2018) Fragmented life: Being a precarious academic between two continents, Revista de Dialectología y Tradiciones Populares, 73 (1), 25-32.

Holmwood, J. (2001) Gender and critical realism: A critique of Sayer, Sociology 35 (4), 947-965, doi.org/10.1177/0038038501035004009

Husu, L. (2019) Gender equality in Nordic academia: Advances and challenges, in D. Vujadinović and Z. Antonijević (eds), Rodna Ravnopravnost U Visokom Obrazovanju: Koncepti, prakse i izazovi, Akademska knjiga, Novi Sad, 63-73.

Ikävalko, E. and Kantola, J. (2017) Feminist resistance and resistance to feminism in gender equality planning in Finland, European Journal of Women's Studies, 24 (3), 233248, doi.org/10.1177/1350506817693868

Ivancheva, M., Lynch, K. and Keating, K. (2019) Precarity, gender and care in the neoliberal academy, Gender, Work \& Organization, 26 (4), 448-462, doi.org/10.1111/gwao.12350

LERU (2019) Equality, diversity and inclusion at universities: The power of a systemic approach, LERU, Leuven.

Lipton, B. (2017) Measures of success: Cruel optimism and the paradox of academic women's participation in Australian higher education, Higher Education Research \& Development, 36 (3), 486-497, doi.org/10.1080/07294360.2017.1290053

Lipton, B. (2019) Closed doors: Academic collegiality, isolation, competition and resistance in the contemporary Australian university, in M. Breeze, Y. Taylor and C. Costa (eds), Time and space in the neoliberal university, Palgrave Macmillan, Cham, 15-42.

Lorenz, C. (2012) If you're so smart, why are you under surveillance? Universities, neoliberalism, and new public management, Critical Inquiry, 38 (3), 599-629.

Mason, M. and Goulden, M. (2004) Marriage and baby blues: Redefining gender equity in the academy, The Annals of the American Academy of Political and Social Science, 596 (1), 86-103, doi.org/10.1177/0002716204268744

Meyers, M. (2013) The war on academic women: Reflections on postfeminism in the neoliberal academy, Journal of Communication Inquiry, 37 (4), 274-283, doi. org/10.1177/0196859913505619 
Morley, L. (2016) Troubling intra-actions: Gender, neo-liberalism and research in the global academy, Journal of Education Policy, 31 (1), 28-45, doi.org/10.1080/026809 39.2015.1062919

Nash, M. (2013) Reflections on teaching gender to Australian sociology undergraduates in the neoliberal postfeminist classroom, Journal of Sociology, 49 (4), 411-425, doi. org/10.1177/1440783313504053

O'Keefe, T. and Courtois, A. (2019) 'Not one of the family': Gender and precarious work in the neoliberal university, Gender, Work \& Organization, 26 (4), 463-479, doi. org/10.1111/gwao.12346

Pereira, M. do Mar (2012) 'Feminist theory is proper knowledge, but . . .': The status of feminist scholarship in the academy, Feminist Theory, 13 (3), 283-303, doi. org/10.1177/1464700112456005

Pereira, M. do Mar (2016) Struggling within and beyond the performative university: Articulating activism and work in an 'academia without walls', Women's Studies International Forum, 54, 100-110, doi.org/10.1016/j.wsif.2015.06.008

Rumens, N. (2018) Teaching gender in a postfeminist management classroom: A gay man's perspective, in Y. Taylor and K. Lahad (eds), Feeling academic in the neoliberal university: Feminist flights, fights and failures, Palgrave Macmillan, Cham, 321-343.

Sagaria, M. (2007) Reframing gender equality initiatives as university adaptation, in M. Sagaria (ed), Women, universities, and change: Issues in higher education, Palgrave Macmillan, New York, 1-6, doi:10.1057/9780230603509_1

Sang, K. (2018) Gender, ethnicity and feminism: An intersectional analysis of the lived experiences feminist academic women in UK higher education, Journal of Gender Studies, 27 (2), 192-206, doi.org/10.1080/09589236.2016.1199380

Sauer, B. and Wöhl, S. (2008) Governing intersectionality: A critical take on diversity politics (authors' own translation), in C. Klinger and G. Knapp (eds), Über-Kreuzungen: Fremdheit, Ungleichheit, Differenz, Westfalisches Dampfboot, Munster.

Schmidt, K. and Cacace, M. (2018) Setting up a dynamic framework to activate gender equality structural transformation in research organizations, Science and Public Policy, 46 (3), 321-338.

Solanke, I. (2017) Black female professors in the UK, March. Available at: www.runnyme detrust.org/uploads/BlackFemaleProfessorsMarch2017.pdf

Steinpórsdóttir, F., Einarsdóttir, P., Heijstra, T. Pétursdóttir, G. and Smidt, T. (2019) Gender budgeting to expose inequalities in a precarious academia - and redistribute resources to effect change, in A. Murgi and B. Poggio (eds), Gender and precarious research careers: A comparative analysis, Routledge, London, 83-110, doi.org/10.4324/9781315201245

Strau $\beta$, A. and Boncori, I. (2020) Foreign women in academia: Double-strangers between productivity, marginalization and resistance, Gender, Work \& Organization, doi.org/10. $1111 /$ gwao. 12432

Téllez, V. (2018) La fortuna de la precariedad, Revista de Dialectología y Tradiciones Populares, 73 (1), 47-53.

Vayreda, A., Conesa, E., Revelles-Benavente, B. and Ramos, A. (2019) Subjectivation processes and gender in a neoliberal model of science in three Spanish research centres, Gender, Work \& Organization, 26 (4), 430-447, doi.org/10.1111/gwao.12360

Winchester, H. and Browning, L. (2015) Gender equality in academia: A critical reflection, Journal of Higher Education Policy and Management, 37 (3), 269-228, doi.org/10.1080/ 1360080X.2015.1034427 